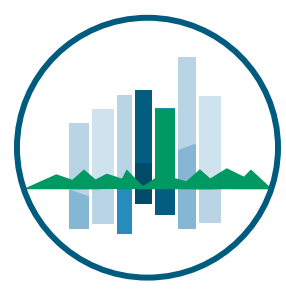

True Smart and Green City? 8th Conference of the International Forum on Urbanism
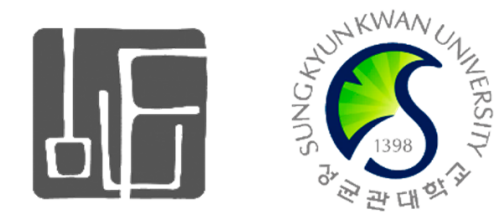

Conference Proceedings Paper

\title{
Urban Project Revisited From Urban Metabolism Principles: Reflections From the UpCycle Workshop in Barcelona
}

\section{Geoffrey Grulois ${ }^{1 *}$ and Carles Crosas Armengol ${ }^{2}$}

1 LoUIsE - Laboratory on Urbanism, Infrastructure and Ecologies, Faculté d'Architecture, Université Libre de Bruxelles, 19 Place Flagey, 1000 Bruxelles, Belgium

2 Department of Urbanism and Regional Planning - DUOT, School of Architecture of Barcelona ETSAB/ Diagonal Av., 649, 08028 Barcelona, Spain

* Author to whom correspondence should be addressed: Tel.: +32-2-645-5649; Fax: +32-2-647-4655; E-mail: geoffrey.grulois@ulb.ac.be.

\begin{abstract}
How to reconnect local urban projects with current global development of smart and green Cities? This paper suggests reemphasising the tradition of urban project by using the principles of urban metabolism and focusing on the economy of material flow: water, energy, goods and transport. While urban projects took as point of departure the ensemble design of architecture, infrastructure and public space for empowering human activity, this paper argue that urban metabolism can expand upon this approach by incorporating environmental concerns into urban design. The scope of the urban project can be redefined beyond the essential short-term goal of human welfare to long-term sustainable ecosystems. UpCycle Zona Franca, a recent academic experience organized by the authors, has focus on the potential of transformation of one of the most privileged industrial areas in the south of Europe, between the port and airport of Barcelona, inviting us to bring closer the theoretical approach to a tentative design practice (Grulois, Casabella, Crosas, Perea).
\end{abstract}

Keywords: Urban design - urban metabolism - industrial estates - Barcelona.

\section{Introduction}

Since the 1980s, the discipline of urbanism in Western Europe has shifted from the abstract regulatory approach of zoning to a more qualitative practice pointing toward the notion of "urban project". This shift from the more orthodox planning to an urban project strategy focuses on proximity to architecture, 
requalification of public space and is characterized by the so called "intermediate scale" and the relation to architecture. The urban renewal of Barcelona for the Olympic Games of 1992, the publication of URUrbanismo Revista (1985-1992) and the theoretical and design works of Manuel de Solà-Morales (2012) clearly contribute to embody a new approach, shared in a common tradition among different countries such as Belgium, France, Spain and Italy, among others.

At present, new environmental issues seem to eclipse the spatial emphazis of urban project : eco efficiency has become the main goal, pointing toward new normative urban models : sustainable neighbourhoods, smart urban block, etc. However the real potentials of urban metabolism to transform strategies and design at the scale of urban project is still to be explored. If urban metabolism (Kennedy et al., 2007) is emerging as a global and multi-scalar approach that focuses on the description and analysis of material flows (Magnaghi, 2000), its urban design and spatial applications are still to be explored.

Figure 1. (a) Map of Barcelona metropolitan territory. Zona Franca is located between the sea and the Lobregat river mouth.

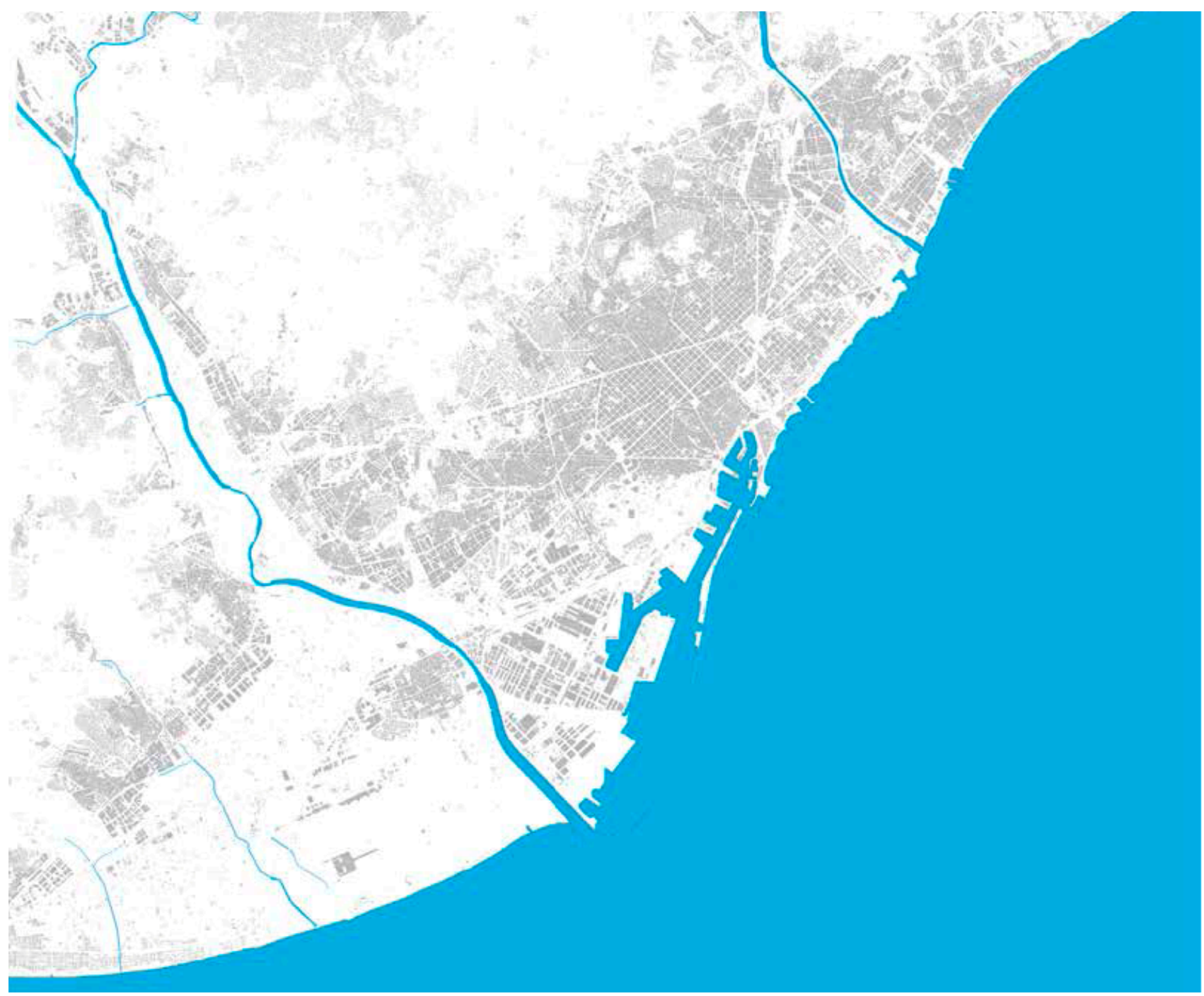




\section{Results and Discussion}

It is well known that the debate on the ecological approach within urban studies has its old roots in the late 19th century, with the pioneering urban planning work introduced by the biologist and sociologist Sir Patrick Geddes. In Barcelona, we can track the roots of an ecological approach in the 1860 Extension plan of Idelfonso Cerda (Solà-Morales ). In 1960s, a renewed global environmental awareness in urban and landscape design emerged in the theoretical work of authors such as McHarg $(1969,1995)$, Hough (1984), Forman (1986, 1995) and Tjallingii (1996). These approaches have crystallized in the discipline of landscape and urban ecology, which emphasizes the role that natural and green spaces can play within the city through concepts such as green infrastructure and ecosystem services, pushing current matters that has not been considered until few years ago.

One step further, urban metabolism emerged in the 1970s with the work of biologists such as Paul Duvigneaud in Belgium, who was the first to conceptualize global material flows in cities, including both natural and industrial ecosystems (Duvigneaud et al., 1977). However, these studies confine themselves to the city scale and are quantitative; they do not provide design tools to formulate spatial solutions for balancing the ecosystems of cities and their regions. Since then, a wide range of literature on detailed and prescriptive concepts concerning urban metabolism has appeared (Kennedy, 2011), in which the concept of the metabolic loop has been developed. Working from within the concept of eco effectiveness, the focus is no longer the objective of reducing the threat of waste and emissions, but rather that waste itself can also be used. The cradle to cradle $(\mathrm{C} 2 \mathrm{C})$ approach (McDonough \& Braungart, 2002) is perhaps the most well known example of eco effectiveness, where waste products are regarded as a resource (nutrient) for the biological cycle or the technological industry cycle. In urban design this approach focuses on capturing - rather than removing - valuable materials and the chemical content of waste and wastewater.

Urban metabolism has found two normative applications with eco-industrial parks (Kalundborg in Denmark and Fujisawa in Japan, for example) and sustainable neighbourhoods (several ongoing initiatives in all Europe). But it remained to explore how to properly conceal architectural design strategies with ecosystemic engineering solutions? The Erasmus Intensive Program - UpCycle Zona Franca - organized in Barcelona in spring 2014 by the Laboratory on Urbanism, Infrastructure and Ecologies (LoUIsE- ULB) and the Laboratory of Urbanism of Barcelona (LUB - ETSAB) in collaboration with Barcelona Regional undertook to explore the redevelopment of the Zona Franca industrial areas. This Erasmus Intensive Program aims to bridge the gap between industrial and landscape ecology by asking how urban metabolism and its design application could become a tool to achieve long-term resilience and sustainability in industrial areas of metropolitan regions, which are facing huge environmental pressure and increasing uncertainty due to the economic crisis.

The aim of the workshop was to go beyond the energy and environmental issues usually addressed individually - for example energy and water efficiency in buildings and green space facilities in cities and to address these from the perspective of urban and landscape design. Behind this was also a wish to raise the status of urban metabolism from a purely technological concept to the level of spatial strategy and quality. How can large-scale industrial areas address the environmental issues of the $21^{\text {st }}$ century? How can we take advantage of global economic flows to upcycle their underlying urban and regional systems? These are some of the questions raised in the workshop. 
Figure 2. Multiscalar analysis of urban flows. Cyan : water; Magenta : material; Orange : energy; Black : transport.

$20 \mathrm{~km} \times 20 \mathrm{~km}$
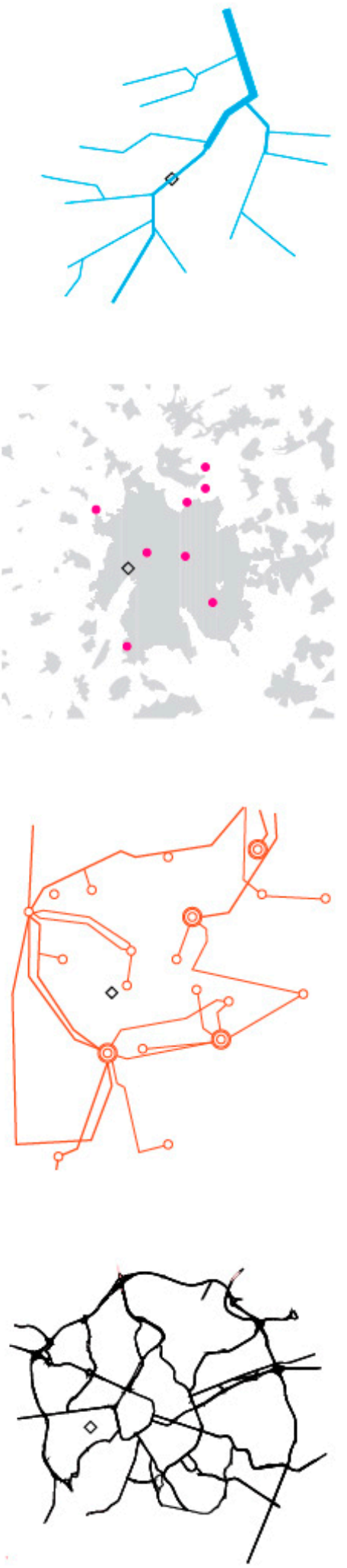
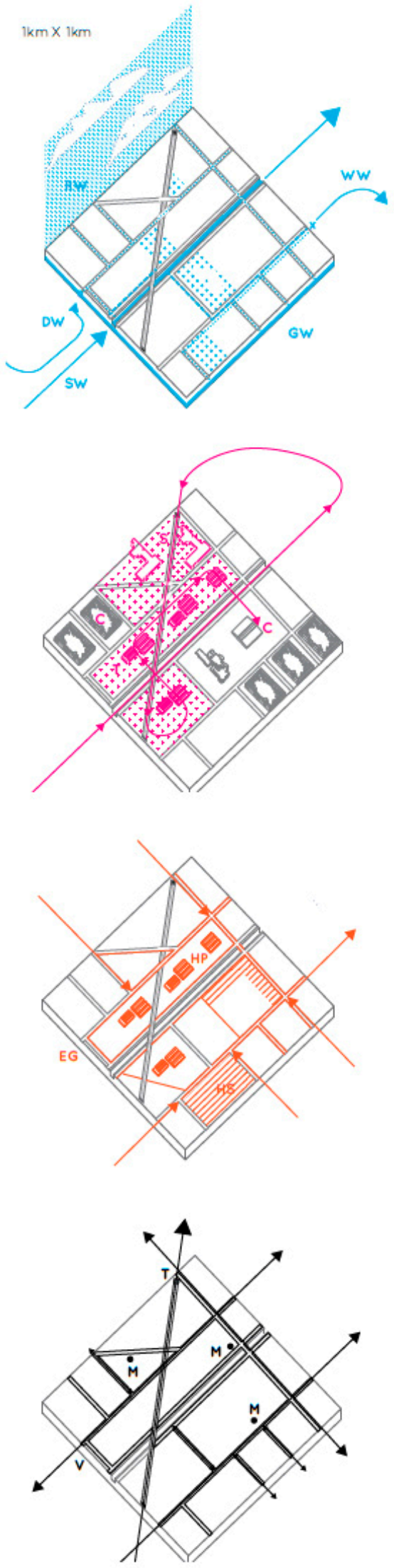


\section{Experimental Section}

The workshop started by studying and redesigning the cycles of water, energy, materials and transport crossing four sites of $1 \mathrm{~km}^{2}$ located in the Zona Franca (the sites are described in the following section of this book). Tracking the cycles of these flows allowed students to understand the interaction of local scale with regional scale and global scale in an ecosystem approach. Following two days of intensive immersion into the specifics of the Zona Franca, which included site visits and lectures by local experts, eight groups of students were asked to develop possible scenarios for the future of the area (2030) by upcycling the four types of flows addressed in the workshop: water, energy, materials and transport. These scenarios were used to try and understand whether the ecosystem approach of urban metabolism, once translated into the spatial context, can be implemented at the level of urban projects and design strategies.

During the second week, the scenarios were worked out into cogenerative design strategies. 'Cogeneration' usually refers to the simultaneous production of electricity and heat by an engine - heat being 'waste' - which is recycled for other uses. The concept of cogenerative design strategies investigates the capacity of every part of an area to play an active role in maintaining the ecological balance of urban metabolism. Upcycling is the process of converting urban waste into new materials with an added value for a city. Within this context the workshop explored urban design strategies that are aimed at resource efficiency, spatial quality and economic dynamism through new programmatic and morphological hybrids that transform each other's 'waste' into new inputs. The workshop emphasized the use of an ecosystems approach that considers all technical and socioeconomic processes that occur in cities and that result in smart growth, economic vitality, efficient use of energy, waste elimination and qualitative space.

The Zona Franca Industrial Estate is the largest modern industrial area in Spain and has been a key factor in Barcelona's economic strength since its construction in the 1950s. Covering an area of about 600 ha, over 300 companies operate in the Zona Franca, employing more than 50,000 workers. Together with the harbour and the new ZAL (logistic activity area), it encompasses a high volume of trade and goods, representing around 3\% of Spain's GDP. Its geographical location provides the Zona Franca with excellent potential: sited in the Delta plain of the Llobregat River, it is separated from the city centre by Montjuic, a prominent hill that pushes the area into the hinterland. Nevertheless, its core is only $7 \mathrm{~km}$ away from the airport and the same distance from the city centre, an attractive aspect in terms of leisure and services. In the 1990s the construction of Barcelona's ring roads (Rondas) linked the local traffic up with the national highway system. The high degree of infrastructure provides excellent accessibility and strong interdependencies with the metropolitan area, but in spatial terms it reinforces its specialized character and functional organization. Gates, loops and segregated types of infrastructure make up a system of progressive enclosures, with delimited areas and few synergies nearby. The harbour and Zona Franca areas play an active role in the metropolitan metabolism because of the concentration of different types of infrastructure they host: eco-park (city waste), a general sewerage collector, a large water treatment plant, a gas pipeline from north Africa and other fluids. Most of these different forms of infrastructure are underused in terms of capacity and could serve a wider area. 
Figure 3. Urban flows in Zona Franca. Cyan : water; Magenta : material; Orange : energy; Black : transport.

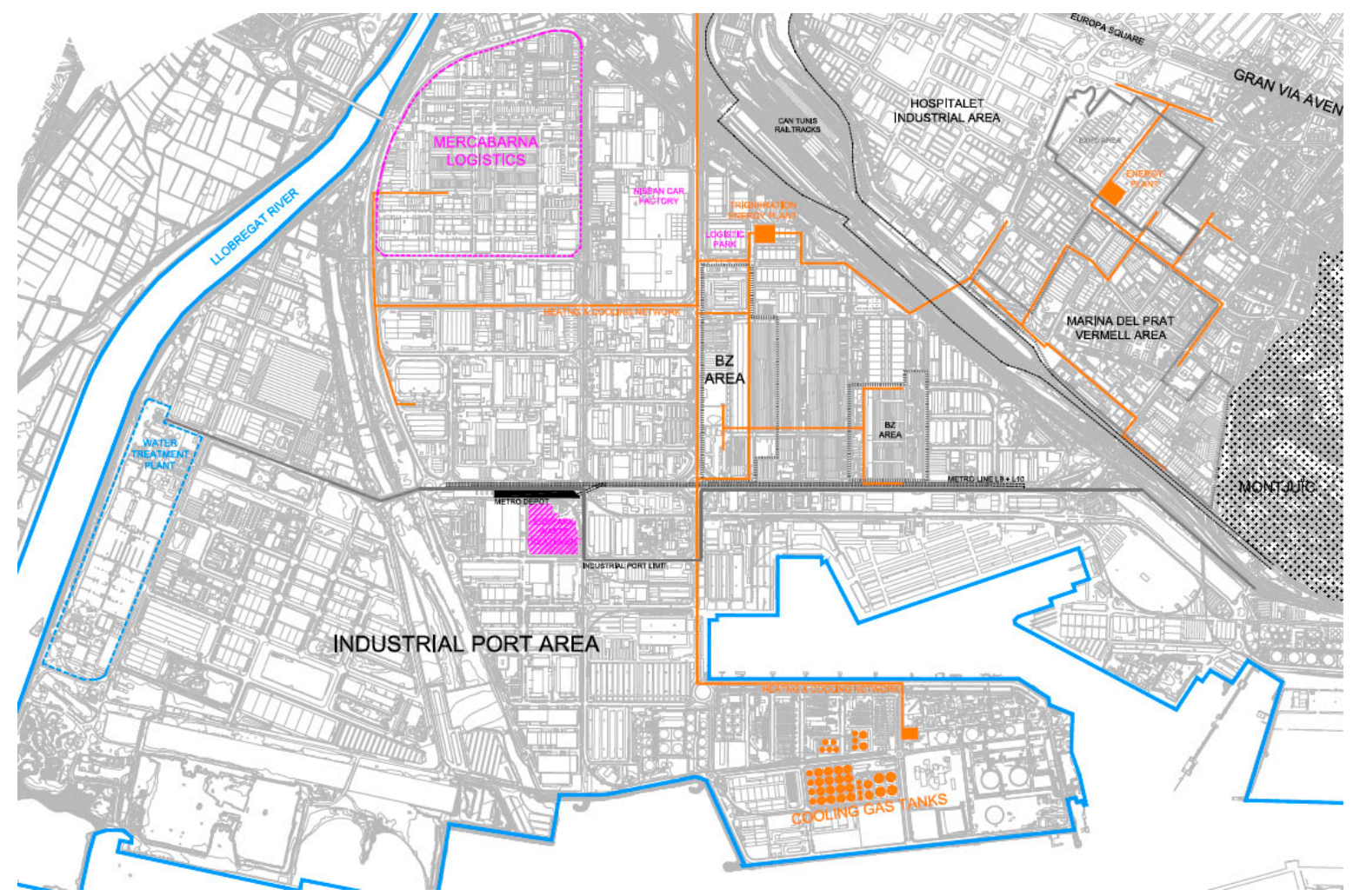

In this framework, the real challenge is to imagine how will this area be retrofitted in the near future, looking at the strong tradition of urban project, but also through a wider ecosystemic approach, where cycles and networks become the main design tools. There are important infrastructure projects on the table that reinforce the accessibility of both the harbour and Zona Franca: new railway tracks connecting with the European rail network, new terminals for containers at the harbour and the future plans for the Ronda Litoral motorway. At the same time, new businesses demand more qualitative urban services as they consider environmental factors as added value.

The scenarii elaborated during the workshop for Zona Franca offer enormous scope, because of its geographical qualities, infrastructure assets and the new energy resource options. The diversification of economies and changes in industrial forms explored offer a wider range of possibilities for making the best use of the Zona Franca's location. Additionally, the presence of two new metro lines (one crossing the area to the airport) with six metro stops opens up new opportunities: we can imagine a more intense and diverse scenario, achieving a definitive break in patterns of isolation with regard to the city.

Focusing on different areas with diverse singularities, all the projects elaborated during the workshop dealt with new urban project methodologies and strategies. The water cycle opportunities are explored in the lower part of Montjuïc, between its slopes and the Ronda Litoral ring road. Beyond the infrastructure, in the waterfront area, developing wetlands can be the argument to collectivize some vacant spaces initially occupied by the port, which now could be recovered by the city with new facilities. On the main Carrer A street, the high accessibility of a new metro stop is the point of departure for developing a new site of activity, where the unnecessary limit between the port and Zona Franca could be erased. There, the current traffic of trucks should interact with public transport, and active mode of 
transport (bike or walking). Achieving a good balance between all is one of the targets. The other is exploring new typologies for a wide range of activities, adapted to our uncertain times and taking advantage of the future network of heating and cooling pipelines crossing vacant plots.

Mercabarna, the large central market that serves a population of almost 10 million inhabitants is an excellent laboratory for some projects in relation with food cycles, in particular for its proximity to the bank of the Llobregat river and the vast agricultural land. New R\&D activities could be incorporated and energy, traffic, water and food could be reconfigured in new ways. Finally, the buffer area created by the Ronda Litoral combined with the high-speed train depots at Can Tunis, on the fringes of the area, need to improve the connection between the industrial areas on both sides. In this way, the effects of urban centrality in the nearby Plaça Europa could extend to the new hub. A new design could widen the current narrow underpass for heavy traffic, adding light traffic, a public transport intersection and powerful energy networks in a more complex configuration.

\section{Conclusions}

All these projects follow the current transformation of urbanism practice in Barcelona to re-incorporate ecological questions. This aim is not truly new, as it also was somehow in the roots of some crucial plans for the city. In the mid $19^{\text {th }}$ century, the plan of Idelfonso Cerdà for the Extension of Barcelona, already addressed issues of natural water flows and green space continuity. Later, in 1891 the engineer Garcia Faria drew an innovative sanitation plan to set up a huge sewerage network system comprising the existing and the future city and the whole Llobregat delta area. In the last decades of the $20^{\text {th }}$ Century, the Olympic project discovered the city waterfront and moulded new beaches, a landmark in Barcelona's urban culture, which merges the intermediate scale and the public space as the main arguments on urban transformation. Beyond these values, the waterfront project is also relevant in terms of urban metabolism: designing a softer and more friendly contact between the asphalt and the sea; the way it made more complex the city traffics in this area, inserting a new ring road and some leisure tours where there was formerly the cut of the railroad; and in particular, developing a praiseworthy project for the integration of the main sewer pipes in a efficient network that is the invisible base of the new landscape of Barcelona beaches.

Some years later, in the late 1990s, when planners had the opportunity to redevelop the final section of the Diagonal towards the sea, they re-introduced the metabolic logic in the design of the Forum area, where precisely great recycling "machines" - the water treatment plant and incinerators - are located at the mouth of Besòs river. At the same time, the redevelopment of 22@ innovative urban district in Poble Nou is exploring new technologies of smart grid and the Llobregat agriculture park is integrating agriculture activities with green space around the metropolis. We hope that the Upcycle Zona Franca workshop will contribute to this current reintegration of ecosyctemic matter in urban design practice.

\section{Acknowledgments}

A European Commission Lifelong Learning Programme funding offered the opportunity for the Faculty of Architecture of Université Libre de Bruxelles (ULB) to organize the UpCycle Zona Franca workshop jointly with Escola Tècnica Superior d'Arquitectura de Barcelona (ETSAB), Universitat Politècnica de Catalunya (UPC). Nadia Casabella and Geoffrey Grulois, from the Laboratory on 
Urbanism, Infrastructure and Ecologies (LoUIsE, ULB), worked jointly with Carles Crosas and Jorge Perea, from Laboratori d'Urbanisme de Barcelona (LUB, UPC), during 6 month to prepare the event. They were assisted by Andrea Bortolotti and Samuel Llovet.

Thanks to an intensive collaboration with local development agency Barcelona Regional, it was possible to ground this research by design workshop in the specific context of Barcelona Zona Franca. They autors want to thank Willy Müller, Juan Carlos Montiel, Marc Montlleó, Jordi Fuster and Aleix Coral for their active collaboration and for the expertise they offered. The autours should also thanks the Concorci de la Zona Franca Barcelona that provided a large office space during two weeks for the organization of the workshop.

The Department of Project Methodology of Università IUAV di Venezia and the Cosmopolis center of Vrije Universiteit Brussel (VUB) also took part in the workshop. The autors would like to thank tutors Jens Aerts, Benoit Moritz, Cristina Renzoni, Michael Ryckwaert, Maria Chiara Tosi and Fabio Vanin for their active involvment in this workshop. should also thanks the 53 students from ULB, UPC, IUAV and ULB that took part in this two weeks intensive programme. The quality of the projects published in the workshop report is a testimony to their dedication.

\section{References and Notes}

1. Erkman S., Vers une écologie industrielle, éditions Charles Léopold Mayer : Paris, France, 1998.

2. Fabian L., Giannotti E., Viganò P., Recycling city. Lifecycles, embodied energy, inclusion, Giavedoni editore: Pordenone, Italy, 2012.

3. Grulois, G., Casabella, N., Crosas, C. and Perea, J. (ed), UpCycle Zona Franca Cogenerative Design Strategies for a Sustainable Urban Metabolism, LoUIsE-ULB and LUB-UPC : Brussels, Belgium, 2015.

4. Forman R.T.T, Gordon M., Landscape Ecology, John Wiley: New York, United States, 1986.

5. Forman, R.T.T, , Land Mosaics: The Ecology of Landscapes and Regions, Cambridge University Press: Cambridge/New York, United States, 1995.

6. Holmes T., Pincetl S., Urban Metabolism Literature Review, Center for Sustainable Urban System UCLA: Los Angeles, United States, 2012.

7. Hough M., City form and natural process: towards a new urban vernacular, Routledge: Toronto, Canada, 1984.

8. Kennedy C., Cuddihy J., Engel-Yan J. The Changing Metabolism of the Cities. Journal of Industrial Ecology, 2007, 11, 43-59.

9. Kennedy C., Pincetls S., Bunje P. The study of urban metabolism and its applications to urban planning and design. Environmental Pollution, 2011, 195, 1965-1973.

10. Magnaghi A., Il progetto locale, Bollati Beringhieri : Torino, Italy, 2000.

11. McDonough W., Braungart M. Cradle to Cradle: Remaking the way we make things, North Point Press: New York, United States, 2002.

12. Odum H. T. Systems ecology: An introduction, Wiley: New York, United States, 1983.

13. Parcerisa, J., Crosas, C. (ed) Barcelona Links, AMB-COAC-ETSAB-LUB: Barcelona, Spain, 2013. 
14. Rapoport E. Interdisciplinary Perspectives on Urban Metabolism: A review on the literature, UCL Development Planning Unit, Working Paper, London, United Kingdom 2011.

15. McHarg I. L. Design with nature, Wiley: New York, United Kingdom, 1995.

16. Rhodes W. K., Koenig A. Escalating trends in the Urban Metabolism of Hong Kong 19711997. Ambio, Vol. 30, No. 7, 2001, 429-438.

17. Solà-Morales, M., Ten lessons on Barcelona : urbanistic episodes that have made the modern city, Actar Editions: Barcelona, Spain, 2008.

18. Solà-Morales, M., A matter of things, Nai Publisher: Rotterdam, Netherland, 2012.

19. Tjallingii S., Ecological Conditions. Strategies and Structures in Environmental Planning, Wageningen: Institute for Forestry and Nature Research, PhD Thesis, Delft, Netherlands, 1996.

20. United Nations, 2011, World Urbanization Prospects, available on http://esa.un.org/unup/

(C) 2015 by the authors; licensee MDPI and IFoU, This article is an open access article distributed under the terms and conditions of the Creative Commons Attribution license. 